\title{
Methane as a Minor Product of Pyruvate Metabolism by Sulphate-reducing and Other Bacteria
}

\author{
By J. R. POSTGATE \\ A.R.C. Unit of Nitrogen Fixation, University of Sussex, \\ Falmer, Brighton, Sussex, BNI $9 Q J$
}

(Accepted for publication 18 April I969)

\begin{abstract}
SUMMARY
Disrupted cells of some Desulfovibrio species, of Desulfotomaculum ruminis and of certain other anaerobes produced methane as a minor product of pyruvic phosphoroclasm. In one Desulfovibrio species the reaction, which was not specially sensitive to air, involved vitamin $B_{12}$, co-enzyme $\mathbf{A}$, thiamine pyrophosphate, magnesium ions and acetyl phosphate. Adenine and other nucleotides stimulated the reaction; a mixture of ATP and AMP was most effective. Methionine stimulated the reaction but the other methyl donors did not. In optimal conditions methane accounted for 0.1 to 0.02 mole $\%$ of the pyruvate metabolized, formed at 20 to $30 \mathrm{nl}$. $\mathrm{CH}_{4} / \mathrm{mg}$. bacterial protein $/ \mathrm{hr}$. Tests in $\mathrm{D}_{2} \mathrm{O}$ indicated that the methane came from the methyl-carbon of pyruvate; correspondingly, ethane formation from $\alpha$-ketobutyrate was detected.
\end{abstract}

\section{INTRODUCTION}

Sisler \& ZoBell (195I) reported that certain cultures of marine sulphate-reducing bacteria, pure by normal criteria, formed methane during growth in lactate + sulphate media. Though occasional references to this finding have appeared, and Sorokin (1956) failed to confirm it, interest has tended to centre on the disputed question of the oxidation of methane (and other hydrocarbons) by desulfovibrios (e.g. Sorokin, 1957; Davis \& Yarbrough, 1966). Methane formation by phosphoroclastic preparations from strains of sulphate-reducing bacteria was reported briefly by Postgate (1969). The present paper describes the reaction in one Desulfovibrio strain in more detail and reports its occurrence in other bacteria.

\section{METHODS}

Cultivation. Desulfovibrio desulfuricans ,variety azotovorans, strain BERRE S (NCIB 8388 ) was grown at $30^{\circ}$ in a $600 \mathrm{ml}$. continuous-culture apparatus (Baker, 1968) at dilution rates ranging from 0.05 to $0 . \mathrm{I} \mathrm{hr}^{-1}$. The medium used was deficient in fixed nitrogen; it contained (g./1.): $\mathrm{KH}_{2} \mathrm{PO}_{4}, 0.5 ; \mathrm{Na}_{2} \mathrm{SO}_{4} 4.5 ; \mathrm{CaCl}_{2} .2 \mathrm{H}_{2} \mathrm{O}, 0.06$; $\mathrm{MgSO}_{4} \cdot 7 \mathrm{H}_{2} \mathrm{O}, 0.06 ; \mathrm{FeSO}_{4} \cdot 7 \mathrm{H}_{2} \mathrm{O}, 0.004$; sodium lactate, 6; sodium citrate, 0.3 (to prevent precipitation of metal hydroxides) in distilled water; plus $10 \mathrm{ml}$. of a trace element mixture containing (mg.): $\mathrm{H}_{3} \mathrm{BO}_{3}, 2 \cdot 32 ; \mathrm{CoSO}_{4} \cdot 7 \mathrm{H}_{2} \mathrm{O}, 95 \cdot 6 ; \mathrm{CuSO}_{4} \cdot 5 \mathrm{H}_{2} \mathrm{O}, 8$; $\mathrm{MnSO}_{4} \cdot 4 \mathrm{H}_{2} \mathrm{O}, 8 ; \mathrm{NaMoO}_{4} \cdot 2 \mathrm{H}_{2} \mathrm{O}, 30 ; \mathrm{ZnSO}_{4} \cdot 7 \mathrm{H}_{2} \mathrm{O}$, 174 in I 1 . distilled water. The complete medium was at $\mathrm{pH} 8 \cdot 2$; the atmosphere was $\mathrm{N}_{2}$ containing 6 to $8 \%(\mathrm{v} / \mathrm{v}) \mathrm{CO}_{2}$. The $\mathrm{CO}_{2}$ buffered the culture to between $\mathrm{pH} 7 \cdot 6$ and 8 , and displaced excess sulphide. 
Effluent was harvested when 0.75 to 31 . had accumulated, the organisms washed by centrifugation in $25 \mathrm{~mm}$-tris buffer $(\mathrm{pH} 7.5 \pm 0 . \mathrm{I})$ and disrupted by dropping a cream of washed bacteria (equiv. 50 to $100 \mathrm{mg}$. dry wt/ml. tris buffer) into liquid nitrogen. Batch cultures of BERRE $S$ and other strains of sulphate-reducing bacteria were grown in long-necked 250 or $500 \mathrm{ml}$. flasks of medium C (Postgate, 1966) under $\mathrm{N}_{2}$ and were disrupted in a similar manner.

Criteria of purity. The strains of sulphate-reducing bacteria were examined microscopically for morphological homogeneity and were tested for both aerobic and anaerobic contamination by using the conditions prescribed by Postgate (1953). No contaminants were found. These procedures might not reveal as contaminants methane-producing bacteria, which are known to associate with sulphate-reducing bacteria (e.g. Stadtman \& Barker, 195I) and which could, if present, have been responsible for the phenomenon being investigated. The continuous culture of strain BERRE $S$, the organisms routinely studied, was therefore examined exhaustively for methane bacteria, by using the media of Stadtman \& Barker (195I) with sodium acetate (the main product after growth in the continuous culture), sodium formate, sodium pyruvate or ethanol $(0.1 \%)$ as carbon sources. Neither 'shake' cultures in such media solidified with agar, nor anaerobic enrichment cultures in stoppered bottles, showed bacterial growth or gas production at $30^{\circ}$. The culture was therefore accepted as free from methane bacteria.

Enzyme assays. Pyruvic phosphoroclastic activity was detected by conventional Warburg manometry at $30^{\circ}$. The preparation under test was set up in a manometer vessel without $\mathrm{KOH}$, gas evolution in response to added pyruvate was observed and finally $\mathrm{CO}_{2}$ was demonstrated in the gas mixture by introducing $\mathrm{IO} \mathrm{N}-\mathrm{KOH}$ and observing gas absorption. Methane formation was detected by vapour-phase chromatography, by the following routine procedure. 'Penicillin vials' of about $8 \mathrm{ml}$. capacity, cooled in ice, were provided with 0.5 to $\mathrm{I} \mathrm{ml}$. tris buffer containing all necessary cofactors (see Results) except for $\mathrm{MgCl}_{2}$ and the substrate pyruvate. A fresh frozen-cell preparation, after 5 to $20 \mathrm{~min}$. in liquid $\mathrm{N}_{2}$, was thawed with I $\mu \mathrm{g}$. each of RNase and DNase under nitrogen or argon to between 0 and $10^{\circ}$ and homogenized by vortexstirring with a Whirlimixer (Scientific Industries (U.K.) Ltd.). Volumes of cell preparation equal to the volumes of co-factor solution already present were distributed among the penicillin vials, usually to give equiv. 8 to $15 \mathrm{mg}$. bacterial protein/vessel. While still cool the vials were flushed with argon and the reaction initiated as soon as possible by injecting pyruvate $+\mathrm{MgCl}_{2}$, transferring the vials to a thermostat bath at $30^{\circ}$ and shaking gently ( 80 to 85 strokes $/ \mathrm{min}$. at amplitude $4 \mathrm{~cm}$.). In a few experiments, nitrogen or other gases replaced argon; in some the reaction system was set up complete with substrates and initiated by warming to $30^{\circ}$; in testing new organisms a control without pyruvate was included. Protein was estimated by the biuret method with serum albumin as standard.

Gas chromatography. The gas phase was sampled by filling a syringe with $0.5 \mathrm{ml}$. argon or other appropriate gas, injecting this and, after a moment for mixing, removing $0.5 \mathrm{ml}$. for chromatography. $\mathrm{CH}_{4}$ was detected and estimated on the Pye 104 gas-liquid chromatograph, with a $5 \mathrm{ft}$. ( $152 \mathrm{~cm}$.) 'Porapak R' column at $75^{\circ}$ or $45^{\circ}$, leading to a flame-ionization detector. The attenuation settings used were to to 50 . The gas was identified as $\mathrm{CH}_{4}$ by infrared spectroscopy in a specially scaled-up experiment. In time-course experiments a correction was made for losses and dilution 
of $\mathrm{CH}_{4}$ involved in the sampling procedure; the correction was imprecise because $\mathrm{CO}_{2}$ and $\mathrm{H}_{2}$, which were produced simultaneously, altered the pressure within the reaction vessel by amounts which varied according to the conditions. In such experiments, therefore, only wide differences in rates of gas production were taken as meaningful.

The argon used contained small amounts of methane $\left(0 \cdot 2\right.$ to I part $\left./ 10^{8}, \mathrm{v} / \mathrm{v}\right)$ which were corrected for; the nitrogen contained none. The argon also contained a similar amount of an unidentified gas running just after hydrogen; though the chromatography detector was a hydrogen flame, very large amounts of hydrogen gave a signal just before the argon impurity peak, and the appearance of such a 'spike' during experiments was a useful indication that a conventional pyruvic phosphoroclasm was in progress.

For the separation of $\mathrm{CD}_{4}$ from $\mathrm{CH}_{4}$ a $5 \AA$ molecular-sieve column (5 ft., $152 \mathrm{~cm}$., 60 to 80 mesh, from F. \& M. Scientific Ltd.) at $25^{\circ}$ replaced the 'Porapak R' column. $\mathrm{CD}_{4}$ (prepared from methyl isocyanide and Azotobacter nitrogenase; Kelly, Postgate \& Richards, 1967) ran ahead of $\mathrm{CH}_{4}$ and was distinguished from it unequivocally by cutting out and superimposing the traces.

Materials. Ordinary chemical reagents were of analytical grade, except some of those used in preparing media. Adenine- and other nucleotides, co-enzyme A, thiamine pyrophosphate, lithium acetyl phosphate, cyanocobalamin, thioctic acid, sodium $\alpha$-ketobutyrate and sodium pyruvate were Sigma products; the ADP contained variable amounts of AMP and was specially purified chromatographically for critical tests.

\section{RESULTS}

Conditions for methane formation. Suspensions of whole bacteria of Desulfovibrio desulfuricans strain BERRE $\mathbf{S}$, harvested from continuous culture with gaseous $\mathrm{N}_{\mathbf{2}}$ as its sole nitrogen source, showed vigorous phosphoroclastic activity. Traces of methane were detected in the overlying gas amounting to I or 2 parts $/ 10^{8}$ formed in $3 \mathrm{hr}$. Methane was not detected above cultures of this strain when growing in sodium lactate media, nor did the strain utilize methane. No growth in excess of the control occurred when medium $\mathrm{C}$ without lactate was inoculated and incubated for $\mathrm{I} 8$ days at $30^{\circ}$ under 1.5 volumes of $\mathrm{N}_{2}+7 \%(\mathrm{v} / \mathrm{v}) \mathrm{CH}_{4}$. 'Blank' growth on the yeast extract in medium $\mathrm{C}$ indicated that these conditions were not intrinsically inimical to growth; no utilization of the $\mathrm{CH}_{4}$ in the atmosphere was detected chromatographically.

Bacterial suspensions disrupted as described in Methods showed much more impressive methane production which varied according to test conditions; suspensions washed with distilled water and dried at $30^{\circ}$ in vacuo were also active. Methane was also produced in $\mathrm{Na}$ phosphate, tris and Na dimethylglutarate buffers (25 mM, $\mathrm{pH} 7 \cdot 5$ ). Bacteria grown in medium $\mathrm{C}$, which contained fixed nitrogen, then frozen and thawed as described in Methods, also gave active preparations. Bacteria from the continuous culture were used in most experiments because they were readily available.

Effects of co-factors. Yates (1967) showed that the phosphoroclastic system of strain BERRE S, like those of certain clostridia (Wiesendanger \& Nisman, 1954; Biggins \& Dilworth, 1968), was stimulated by ATP. Figure I illustrates stimulation of methane formation by ATP. Acetyl phosphate occasionally stimulated the system; Yates routinely added certain known co-factors of the phosphoroclastic system; 
the following co-factors stimulated methane production by BERRE $S$ preparations in $25 \mathrm{mM}$ tris $\mathrm{pH}_{7.5}$ (optimal concentrations are given in parentheses): $\mathrm{MgCl}_{2}$ (2.5 mM), $\mathrm{KH}_{2} \mathrm{PO}_{4}$ (I.6 mM), co-enzyme A (0.5 mg. $/ \mathrm{ml}$ ), thiamine pyrophosphate $(0.05 \mathrm{mg} . / \mathrm{ml}$.), acetyl phosphate $(0.5 \mathrm{mg}$. $/ \mathrm{ml}$.), ATP (I mM). The concentration of co-enzyme A required for maximum activity was unexpectedly large but was indeed necessary; it could not be replaced by equimolar cysteine. No unequivocal effect of $\alpha$-lipoic acid $\left(0.5 \mathrm{mg} . / \mathrm{ml}\right.$.) was detected; $\mathrm{K}^{+}$as $\mathrm{KCl}(5 \mathrm{mM})$ did not affect the reaction. Ferredoxin, rubredoxin and cytochrome $c_{3}$ extracted from strain BERRE $S$ were tested as concentrates after ion-exchange chromatography (50 to $55 \mu \mathrm{g}$. carrier $/ \mathrm{ml}$.): ferredoxin and rubredoxin depressed methane production slightly; cytochrome $c_{3}$ had no effect. No clear effect on hydrogen production by any of these factors was observed.

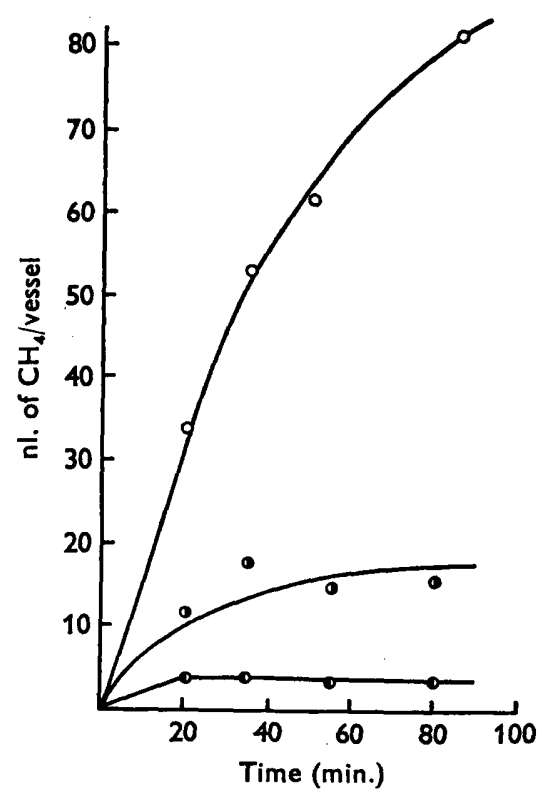

Fig. I. Effect of ATP on methane production by Desulfovibrio desulfuricans strain BERRE S disrupted by freezing in liquid nitrogen. Reaction mixture $(2 \mathrm{ml}$.) contained acetyl phosphate, co-enzyme $\mathbf{A}$, cyanocobalamin, thiamine pyrophosphate and potassium phosphate in tris buffer and equiv. $8.1 \mathrm{mg}$. bacterial protein at $30^{\circ}$ under argon in an $8 \mathrm{ml}$. penicillin vial; for details see text. O, ATP (I mM), $\mathrm{MgCl}_{2}(2.5 \mathrm{mM})$ and sodium pyruvate $(7.5 \mathrm{mg} . / \mathrm{ml}$.) added to start reaction; 1 , ATP omitted: 1 , pyruvate omitted. A boiled control showed no activity.

Blaylock \& Stadtman (1963, 1964) showed that a methane-producing system from Methanosarcina barkerii utilized cobalamin derivatives and that methyl $\mathrm{B}_{12}$ was an intermediate. Cyanocobalamin stimulated methane production by the BERRE $\mathbf{S}$ preparation and showed optimal activity at 5 to $50 \mu \mathrm{g} . / \mathrm{ml}$; $500 \mu \mathrm{g} . / \mathrm{ml}$. depressed activity by about $60 \%$. During the reaction the pink $\mathrm{B}_{12}$ colour became bleached, suggesting that reduced intermediates capable of accepting methyl groups were being formed.

On the basis of these findings a standard reaction mixture was formulated for other 
tests containing ATP, I mM; $\mathrm{KH}_{2} \mathrm{PO}_{4}, 2.5 \mathrm{mM}$; thiamine pyrophosphate, $0 . \mathrm{I} \mathrm{mg} . / \mathrm{ml}$., co-enzyme A, I mg./ml.; lithium acetyl phosphate, I mg./ml.; cyanocobalamin, $0.01 \mathrm{mg} . / \mathrm{ml}$. tris buffer $(0.025 \mathrm{M}, \mathrm{pH} 7.5)$. Sodium pyruvate $(15 \mathrm{mg} . / \mathrm{ml}$. $)+\mathrm{MgCl}_{2}$ ( $5 \mu$ mole) were generally injected in $0.1 \mathrm{ml}$. buffer to initiate reaction; in certain tests ATP or substitute nucleotides were omitted from the reaction mixture and injected with the substrates.

Effect of $p H$ value, pyruvate and enzyme concentration. Methane was produced more rapidly at $\mathrm{pH} 7.5$ than at $\mathrm{pH} 7$ or 8 . Pyruvate was necessary for methane formation (Fig. I). Between Io and $100 \mathrm{mg}$. sodium pyruvate/ml. the rate of production of $\mathrm{CH}_{4}$ decreased, though the final amount did not necessarily do so; the initial rate was constant between I and $10 \mathrm{mg}$. pyruvate/ml. but the rate always decreased with time (see Fig. I). The reaction rate with $5 \mathrm{mg}$. pyruvate/ml. was proportional to 'enzyme' concentration between equiv. 7 and $25 \mathrm{mg}$. bacterial protein $/ \mathrm{ml}$. but decreased at $35 \mathrm{mg} . / \mathrm{ml}$.

Effect of air. Extracts of Methanobacterium omelianskii are extremely sensitive to air (Wolin, Wolin \& Wolfe, 1963). Preparations of Desulfovibrio desulfuricans strain BERRE $S$ were not unduly sensitive: equiv. $6.3 \mathrm{mg}$. bacterial protein/vessel ( $2 \mathrm{ml}$. fluid) yielded 12.6 to $17.4 \mathrm{nl} . \mathrm{CH}_{4} / \mathrm{mg}$. protein $/ \mathrm{hr}$ under air, nitrogen + air to $0.02 \mathrm{~atm} . \mathrm{O}_{2}$, or pure $\mathrm{N}_{2} \cdot \mathrm{CO}_{2}$ was formed in all conditions. A preparation of equiv. $8.5 \mathrm{mg}$. protein $/ \mathrm{ml}$. retained $65 \%$ of the activity of a control in argon after stirring vigorously in air for I min. with a vortex mixer. This relative insensitivity to oxygen makes it unlikely that the stimulating effect of cyanocobalamin was due to scavenging of residual oxygen by the catalytic effect of vitamin $B_{12}$ on thiol oxidation (Peel, 1963). Nevertheless, this possibility was tested by using sodium dithionite to remove oxygen; cyanocobalamin stimulated the reaction equally well whether $\mathrm{Na}_{2} \mathrm{~S}_{2} \mathrm{O}_{4}$ $(0.5 \mathrm{mg} . / \mathrm{ml}$.) was present or not.

Effects of reaction products. The major products of pyruvic phosphoroclasm in desulfovibrios are acetate (by way of acetyl phosphate), $\mathrm{CO}_{2}, \mathrm{H}_{2}$ and/or ethanol (Millet, 1954; Sadana, 1954). Acetyl phosphate yielded no methane alone but, in the presence of pyruvate, was a strong stimulant of $\mathrm{CH}_{4}$ production. It was routinely present in the reaction mixtures. Sodium acetate $(0.5 \mathrm{mg} . / \mathrm{ml}$.) had no effect; phosphoenol pyruvate (0.5 mg./ml.) was also inactive. $\mathrm{CH}_{4}$ was formed under helium or $\mathrm{N}_{2}$ as well as under argon, but an atmosphere of $\mathrm{H}_{2}$ decreased the rate of production and yield by about $55 \% . \mathrm{CO}_{2}$, either $3 \%(\mathrm{v} / \mathrm{v})$ in the atmosphere or as $0.5 \mathrm{mg} . \mathrm{NaHCO}_{3} / \mathrm{ml}$. in the reaction mixture, decreased the amounts of methane formed by 60 to $75 \%$. Ethanol (0.5 mg./ml.) inhibited methane production by $95 \%$.

Other substrates and inhibitors. Sodium formate, which undergoes the hydrogenlyase reaction in Desulfovibrio (Ishimoto, Yagi \& Shiraki, 1957), yielded no methane at $0.5 \mathrm{mg} . / \mathrm{ml}$. Sodium $\alpha$-ketobutyrate was metabolized by preparations of $D$. sulfuricans strain BERRE $S$ with a nominal $Q_{\mathrm{co}_{2}}$ of $4.8 \mu \mathrm{l} . \mathrm{CO}_{2} / \mathrm{mg}$. bacterial protein $/ \mathrm{hr}$ as compared with a control $Q_{\mathrm{co}}$ value of 2'I4 without substrate and of 40 with pyruvate (for calculating these values all the gaseous product was taken to be $\mathrm{CO}_{2}$ though, with pyruvate, some was $\mathrm{H}_{2}$ ); $\alpha$-ketobutyrate depressed the 'blank' methane production by such preparations but ethane was detected in the overlying gas, formed at about $0.6 \mathrm{nl}$./mg.bacterial protein $/ \mathrm{hr}$. Methanol or propanol $(0.5 \mathrm{mg} . / \mathrm{ml}$.) decreased the rate and amount of methane formation by $58 \%$ and $90 \%$, respectively; butanol, at a similar concentration, had no influence on the reaction. Methylviologen $(0 \cdot 25 \mathrm{mM})$ completely 
inhibited methane formation but stimulated formation of hydrogen. Methylviologen has a comparable effect on methane formation by washed Methanobacterium omelianskii (Wolin, Wolfe \& Wolin, 1964).

Effects of biological methylating agents. Choline chloride $(0.5 \mathrm{mg} . / \mathrm{ml}$.) had no effect on methane formation. Methionine ( 0.05 to $\mathrm{I} \mathrm{mM}$ ) stimulated the reaction moderately in five tests out of six; S-adenosyl methionine $(0.5 \mathrm{mg} . / \mathrm{ml}$.), which might have been formed from ATP and methionine, had no effect when tested as the iodide, in place of both ATP and methionine.

Effects of nucleotides. Reaction mixture made up without ATP was tested with ADP or AMP at I mM or pairs of adenine nucleotides at $0.5 \mathrm{~mm}$ each. For these tests specially purified ADP was used. In four separate tests, no single nucleotide was more effective than ATP and ADP was generally the least effective. But mixtures of nucleotides had profound effects, though test-to-test variations were considerable. ATP + AMP had maximum effect on one occasion but did not exceed ATP alone on another. Equimolar amounts of other nucleotide triphosphates replaced ATP: guanosine triphosphate and uridine triphosphate were about as effective as ATP, cytidine triphosphate showed $50 \%$ activity, inosine triphosphate was inactive.

\section{Table I. Stoichiometry of methane production by Desulfovibrio desulfuricans} strain BERRE $S$ during pyruvic phosphoroclasm

\begin{tabular}{|c|c|c|c|c|c|}
\hline $\begin{array}{c}\text { mg. bacterial } \\
\text { protein } / \mathrm{ml} \text {. }\end{array}$ & $\begin{array}{l}\text { Incubation } \\
\text { (min.) }\end{array}$ & $\underset{(\mu \text { mole })}{\mathrm{CO}_{2}}$ & $\underset{(\mu \text { mole })}{\mathbf{H}_{2}}$ & $\underset{\text { (nmole) }}{\mathrm{CH}_{4}}$ & $\begin{array}{c}\mathrm{CH}_{4} \text { as } \\
\text { mole } \% \mathrm{CO}_{2}\end{array}$ \\
\hline $\begin{array}{l}35^{*} \\
24\end{array}$ & $\begin{array}{l}23 \\
30\end{array}$ & $\begin{array}{r}8 \cdot 8 \\
16 \cdot 1\end{array}$ & $\underline{9 \cdot 3}$ & $\begin{array}{r}4 \cdot 7 \\
38 \cdot 0\end{array}$ & $\begin{array}{l}0.053 \\
0.24\end{array}$ \\
\hline 50 & 45 & $12 \cdot 4$ & $15 \cdot 5$ & $7 \cdot 0$ & 0.56 \\
\hline $33 \uparrow$ & 50 & $5 \cdot 0$ & 0.56 & $7 \cdot 2$ & $I \cdot 4$ \\
\hline $9 \cdot 2\} \ddagger$ & 55 & $9 \cdot I$ & $2 \cdot 2$ & 0.48 & 0.053 \\
\hline $9 \cdot 2 \int$ & 65 & 7.05 & $4 \cdot 5$ & 0.38 & 0.051 \\
\hline 7 & I 10 & I I 4 & 0.7 & $2 \cdot 87$ & 0.025 \\
\hline $7 \cdot 7 \S$ & 155 & $20 \cdot 4$ & 0.75 & 2.57 & 0.0126 \\
\hline \multicolumn{6}{|c|}{$\begin{array}{l}0.5 \mathrm{mg} \text {. DL-methionine/ml. reaction vessel present. } \\
\text { Bacteria grown with fixed-nitrogen (note relatively low } \mathrm{CO}_{2} \text { and } \mathrm{H}_{2} \text { output). } \\
\text { Same bacterial preparations. }\end{array}$} \\
\hline
\end{tabular}

Stoichiometry. Blaylock \& Stadtman (1963) noted that a considerable consumption of pyruvate was required to generate relatively little methane by extracts of Methanosarcina barkerii. Preparations of Desulfovibrio desulfuricans strain BERRE $\mathbf{S}$ were studied in 2-side arm Warburg flasks with a 'Suba-seal' closure on one arm to permit removal of gas samples and injections of alkali for gasometric $\mathrm{CO}_{2}$ analysis. Table I quotes selected results from eight experiments and illustrates three points. (I) Methane was formed in greater proportions early in the reaction. (2) The theoretical $\mathrm{CO}_{2}: \mathrm{H}_{2}$ ratio of $\mathrm{I}$ for pyruvic phosphoroclasms was rarely obtained, and the $\mathrm{H}_{2}$ yield was generally low. This finding was checked by experiments using gas-chromatographic analysis for $\mathrm{CO}_{2}$ and $\mathrm{H}_{2}$ with a gas-density detector: the situation was attributed to 
hydrogen consumption by endogenous hydrogen acceptors in the strongly proteinaceous preparations necessary for this work: freshly disrupted strain BERRE $S$ preparations had initial $-Q_{\mathrm{H}_{2}}$ values of about $\mathrm{I} 6 \mu \mathrm{l}$. $\mathrm{H}_{2} / \mathrm{mg}$. protein $/ \mathrm{hr}$. (3) Methane accounted for between 0.02 and 0.2 mole $\%$ of the pyruvate utilized, considerably less than the 3 to 7 mole \% methane which Blaylock \& Stadtman (1963) observed with Methanosarcina barkerii and methyl $\mathrm{B}_{12}$ as co-factor.

Origin of the methane. The experiments in which ethane was formed from $\alpha$-ketobutyrate suggested that the ethane originated from the alkyl chain of the substrate, not by $\mathrm{CO}_{2}$ reduction. This conclusion was checked by tests in $\mathrm{D}_{2} \mathrm{O}$, which would give $\mathrm{CD}_{4}$ by a $\mathrm{CO}_{2}$-reduction mechanism but $\mathrm{CH}_{3} \mathrm{D}$ (chromatographically indistinguishable from $\mathrm{CH}_{4}$ in my test system) by a reductive decarboxylation mechanism. Bacteria preequilibrated $20 \mathrm{~min}$. at $30^{\circ}$ with $\mathrm{D}_{2} \mathrm{O}$ buffer and vacuum-dried bacteria re-constituted in $\mathrm{D}_{2} \mathrm{O}$ buffer were tested; both yielded peaks indistinguishable from $\mathrm{CH}_{4}$. Insufficient gas was found for identification of $\mathrm{CH}_{3} \mathrm{D}$ by infrared spectroscopy.

\title{
Table 2. Methane-producing activity of disrupted sulphate-reducing and other bacteria
}

\begin{abstract}
Washed organisms were disrupted in liquid $\mathrm{N}_{2}$ and shaken under argon at $30^{\circ}$ with 5 to $20 \mathrm{mg}$. sodium pyruvate/ml. reaction mixture (see text). Bacterial protein 3 to $30 \mathrm{mg}$./vessel according to activity; negative or 'trace' tests ran for 90 to $180 \mathrm{~min}$., positives ran for 30 to $50 \mathrm{~min}$. All preparations showed $\mathrm{CO}_{2}$ and/or $\mathrm{H}_{2}$ production from pyruvate; Clostridium pasteurianum and Bacillus polymyxa were not tested.
\end{abstract}

Species and strain with N.C.I.B. number

Sulphate-reducing bacteria

Desulfovibrio desulfuricans BERRE S (8388)

D. africanus BENGHAZI (840I)

D. salexigens BRITISH GUIANA (8403)

Desulfotomaculum ruminis COLEMAN 42 (10,149)

Others

Clostridium pasteurianum strain $\mathrm{w}$

\author{
$\mathrm{CH}_{4}$ produced \\ (nl./mg. \\ protein/hr.)
}

$$
\begin{gathered}
15-20 \\
0.16 \\
1.7 \\
9.5-11 \\
\\
2.65
\end{gathered}
$$

Methane at less than $0.1 \mathrm{nl} . / \mathrm{mg}$. hr. was formed by Desulfovibrio desulfuricans BERRE E (8387), Desulfovibrio vulgaris 'HIDENBOROUGH' (8303), Desulfovibrio gigas (9332), Klebsiella pneumoniae and Bacillus polymyxa. No methane was formed by Desulfovibrio desulfuricans 'ESSEX 6' (8307) or NORWAY 4 (8310), nor by Rhodospirillum rubrum.

Tests of other bacteria. Batches ( $250 \mathrm{ml}$.) of sulphate-reducing bacteria were grown in medium $\mathrm{C}$ under nitrogen, harvested and disrupted in liquid nitrogen as described. The preparations were tested in the usual reaction mixture for methane formation, and pyruvic phosphoroclastic activity was tested by Warburg manometry. Table 2 lists the strains tested; activity was not restricted to any particular species or even genus and not all strains of a species were active. Some were tested twice and showed wide differences; only Desulfotomaculum ruminis approached the activity of the BERRE $\mathbf{S}$ strain of Desulfovibrio desulfuricans. Non-sulphate-reducing bacteria were obtained from Dr M. Kelly (this laboratory) as live cultures or frozen suspensions grown in conventional nitrogen-deficient media for 2 to 4 days at $30^{\circ}$; phosphoroclastic activity was obvious in the preparation of Clostridium pasteurianum because a 'hydrogen spike' (see Methods) was observed in the chromatographic tests. The presence of 
chalk carried over from the culture medium precluded a satisfactory manometric test for pyruvic phosphoroclasm with this strain and Bacillus polymyxa. Clostridium pasteurianum was tested with sodium $\alpha$-ketobutyrate, from which it formed a trace of ethane.

\section{DISCUSSION}

Methane is unequivocally a minor product of pyruvic phosphoroclasm in a majority of the strains of sulphate-reducing bacteria tested and cannot reasonably be attributed to contaminant methane bacteria. It is produced in insufficient amounts to account for the stimulation of pyruvic phosphoroclasm in Desulfovibrio desulfuricans strain BERRE $S$ as recorded by Yates (1967). The strains differed in their productivities, as Sisler \& ZoBell (I95I) reported among the cultures they surveyed, and though amounts of methane comparable with Sisler \& ZoBell's maximum yields were not encountered over live cultures, it is reasonable to suppose that differences in strains and test conditions used account for this discrepancy and for Sorokin's (1956) failure to confirm Sisler \& ZoBell's report.

A soluble methane-producing system was not studied because attempts to extract a soluble pyruvic phosphoroclastic system from Desulfovibrio desulfuricans strain BERRE $S$ have not so far been successful. The properties of the particulate preparations, though not always as clear-cut as might be expected from soluble enzymes, resemble in certain details those of the extracts of Methanosarcina barkerii studied by Blaylock \& Stadtman (1963, 1964; see also Stadtman, 1967 ): vitamin $B_{12}$ is involved (it stimulates and becomes bleached during the reaction), and adenine nucleotides stimulate. But the source of the methane is the 3-C group of pyruvate, which it is not in extracts of M. barkerii. As in true methane bacteria, the yield of methane is low in terms of pyruvate consumed. This feaure also recalls the low ammonia yield in the cell-free nitrogen-fixing phosphoroclastic system from Clostridium pasteurianum studied by Carnahan, Mortenson, Mower \& Castle (1960), but there seems to be no direct connexion between methane formation and nitrogen fixation, since (I) ammonia-grown populations of $D$. desulfuricans strain BERRE $\mathrm{S}$ formed methane, (2) non-nitrogen-fixing strains such as Desulfovibrio salexigens formed methane, (3) several nitrogen-fixing anaerobesdid not form methane. The yield of $\mathrm{CH}_{4}$ from pyruvate with strain BERRE S was I 5 to I 50 times lower than that recorded for $M$. barkerii; it might have been improved had methyl $\mathrm{B}_{12}$, the functional co-factor in $M$. barkerii, been available, but this reaction is clearly a smallscale process in physiological terms. Amajor difference between the Desulfovibrio system and that in a true methane bacterium is its relative insensitivity to oxygen. Minor differences include activity of acetyl phosphate, not reported among the methane bacteria, which may result from a peculiarity of the phosphoroclastic system of strain BERRE S. The enhanced activity of nucleotide mixtures and the effects of GTP, UTP etc. may be related to the crudity of the test system.

Relatively little of the energy and/or reducing power of the phosphoroclastic system is channelled into methane formation and it is reasonable to assume that the extent of channelling depends on the molar ratios of ATP, acetyl phosphate, co-enzyme A and their derivatives, which will normally assume steady states during the decomposition of pyruvate. It is difficult to draw precise conclusions about the influences of these factors added as single substances, when their addition in large amounts will drastically influence the steady state concentration of the others. It seems likely that the need for 
large amounts of co-enzyme $A$ reflected a necessity to unbalance a control system which normally limits drastically the amounts of methane formed.

There are reasons for regarding methane production, pyruvic phosphoroclasm, nitrogen fixation and non-haem-iron electron transport as biologically primitive reactions. Peck (1967) and Klein \& Cronquist (1967) have proposed that both methane-producing bacteria and sulphate-reducing bacteria are present-day representatives of very primitive living things. The existence of a methane-producing system, biochemically similar to that in methane bacteria, in one of the sulphatereducing bacteria, together with the detectable activity of comparable systems in some other bacteria capable of pyruvic phosphoroclasm, adds weight to this view. Methane formation in Desulfovibrio species and the other non-methane bacteria may be a 'vestigial' biochemical process of the kind proposed by Kelly (1968) for Thiobacillus neapolitanus and by Gottschalk (1968) for desulfovibrios and certain clostridia.

\section{REFERENCES}

BAKer, K. (1968). Low cost continuous culture apparatus. Lab. Pract. 17, 817.

Bigains, D. R. \& Dilworth, M. F. (I968). Control of pyruvic phosphoroclastic activity in extracts of Clostridium pasteurianum by ADP and acetyl phosphate. Biochim. biophys. Acta 156, 285 .

Blaylock, B. A. \& Stadtman, T. C. (1963). Biosynthesis of methane from the methyl moeity of methyl cobalamin. Biochem. biophys. Res. Commun. II, 34.

Blaylock, B. A. \& Stadtman, T. C. (1964). Enzymic formation of methyl cobalamin in Methanosarcina barkerii extracts. Biochem. biophys. Res. Commun. 17, 479.

Carnahan, J. E., Mortenson, L., Mower, H. F. \& Castle, J. E. (1960). Nitrogen fixation by cellfree extracts of Clostridium pasteurianum. Biochim. biophys. Acta 38, 188.

Davis, J. B. \& YARBRouGH, H. F. (1966). Anaerobic oxidation of hydrocarbons by Desulfovibrio desulfuricans. Chem. Geol. I, 137.

GotschalK, G. (1968). The stereospecificity of the citrate synthase of sulfate-reducing and photosynthetic bacteria. Eur. J. Biochem. 5, 346.

Ishimoto, M., YAGI, T. \& ShIRAKI, M. (1957). Biochemical studies on sulfatereducing bacteria VIII. The function of cytochrome of sulfate-reducing bacteria in decomposition of formate and reduction of sulfur and hydoxylamine. J. Biochem., Tokyo 44, 707.

Kelly, D. P. (1968). Fluoroacetate toxicity in Thiobacillus neapolitanus and its relevance to the problem of obligate chemo-autotrophy. Arch. Mikrobiol. 6r, 59.

Kelly, M., Postgate, J. R. \& RichaRds, R. L. (1967). Reduction of cyanide and isocyanide by nitrogenase of Azotobacter chroococcum. Biochem. J. I02, I C.

KleIN, R. M. \& Croneust, A. (1967). A consideration of the evolutionary and taxonomic significance of some biochemical, micromorphological and physiological characters in the thallophytes. Q. Rev. Biol. 42, 105.

Millet, J. (1954). Dégradation anaérobie du pyruvate par un extrait enzymatique do Desulfovibrio désulfuricans. C. r. hebd. Séanc. Acad. Sci., Paris 238, 408.

Peck, H. D. (1967). Some evolutionary aspects of inorganic sulfur metabolism. Lectures on Theoretical and Applied Aspects of Microbiology. University of Maryland.

Peel, J. L. (1963). The catalysis of the auto-oxidation of 2-mercaptoethanol and other thiols by vitamin $\mathbf{B}_{12}$ derivatives. Biochem. J. 58, 296.

Postgate, J. R. (1953). On the nutrition of Desulfovibrio desulfuricans: a correction. J. gen. Microbiol. $9,440$.

Postgate, J. R. (1966). Media for sulphur bacteria. Lab. Pract. 15, 1239.

Postgate, J. R. (I969). Methane as a minor product of pyruvic phosphoroclasm in Desulfovibrio. J. gen. Microbiol. 55, xv.

Sadana, J. (1954). Pyruvate oxidation in Desulfovibrio desulfuricans. J. Bact. 67, 547.

SiSLER, F. D. \& ZoBell, C. E. (1951). Hydrogen utilization by some marine sulfate-reducing bacteria. J. Bact. 62, II 1 . 
SorokIN, Y. (1956). Study of cultures of sulphate-reducing bacteria isolated from some natural materials of the country round Bajkal. Proc. Bajkal Limnol. Stn 15, 397. (In Russian.)

Sorokin, Y. (1957). Contribution to the question of utilization of methane for the formation of sulphide by sulphate-reducing bacteria. C.R. Acad. Sci., U.S.S.R. 115, 816. (In Russian.)

Stadtman, T. C. (1967). Methane fermentation. A. Rev. Microbiol. 21, I21.

StadtMan, T. C. \& Barker, H. A. (195I). Studies on the methane bacteria. VIII. Tracer experiments on fatty acid oxidation by methane bacteria. J. Bact. 6r, 57.

WIESENDANGer, S. B. \& Nisman, B. (1954). Rôle de l'ATP et du CoA dans la déshydrogénation du pyruvate par les extraits de C. saccharobutyricum. Biochim. biophys. Acta 13, 480.

Wolin, E. A., Wolfe, R. S. \& Wolin, M. J. (1964). Viologen dye inhibition of methane formation by Methanobacillus omelianskii. J. Bact. 87, 493.

Wolin, E. A., Wolin, M. J. \& Wolfe, R.S. (1963). Formation of methane by bacterial extracts. J. biol. Chem. 238, 2882.

YATES, M. G. (1967). Stimulation of the phosphoroclastic system of Desulfovibrio by nucleotide triphosphates. Biochem. J. 103, 32c. 